\title{
Insight
}

ChINA \& WTO ReV. 2019:1; 195-206

http://dx.doi.org/10.14330/cwr.2019.5.1.10

pISSN 2383-8221 • elSSN 2384-4388

China and WTO Review

\section{The Forum on China-Africa Cooperation: An Investment Perspective}

\author{
Zhiyuan Wen* \\ Xiamen University
}

The investment-related initiatives have been included in the FOCAC since its beginning. The investment promotion initiative is consistent, mutually sustainable, and goal-clear; the investment protection initiative relies on the protection from domestic and international law; the investment facilitation initiative becomes more important; the investment dispute resolution initiative proposes a creative new choice. Due to investment-related initiatives, the FDI between China and Africa is growing, the bilateral investment treaties are in progress, the investment facilitation situation is improved, and a new dispute resolution institution appears. The investment-related initiatives of FOCAC achieves great success to date.

Keywords: FOCAC, Investment Promotion, Investment Protection, Investment Facilitation, Dispute Resolution

\section{Introduction}

In September 2018, the Summit of the FOCAC was held in Beijing. Jointly established by China and Africa in 2000, the FOCAC is one of the most important platforms between China and Africa, whose objectives are promoting equal consultation, enhancing understanding, expanding consensus, strengthening friendship and improving cooperation. ${ }^{1}$ In fact the 2018 Beijing Summit is the seventh Ministerial Conference of the FOCAC mechanisms, which is held once

* Ph.D. candidate of International Law at Xiamen University, P. R. China. The author can be contacted at: zy-wen@foxmail.com/Address: School of Law, Xiamen University, 422 Siming Nan Road, Xiamen 361005, China. 
in three years by China and Africa. The Senior Officials' Follow-up Meeting and the Senior Officials' Preparatory Meeting for the Ministerial Conference are held respectively in that year a few days before the Ministerial Conference. In addition, the consultations between the African Diplomatic Corps in China and the Secretariat of the Chinese Follow-up Committee are held at least twice a year. $^{2}$ The Ministerial Conference is the only mechanism that will come up with declarations and actions plans, which contain the initiatives of future actions. To this day, the FOCAC has held seven Ministerial Conferences and put forward several declarations and action plans (Table 1). Through these seven conferences, the FOCAC has been fulfilling its objectives gradually, by implementing the initiatives about industrialization, agriculture, infrastructure, finance, environment, trade, investment, public welfare, etc.

This essay will only address the investment-related initiatives of the FOCAC and analyze their effects and implications. The perspective of investment-related initiatives will show the progress and achievement of the FOCAC more vividly.

Table 1: Years, Places, and Documents of Ministerial Conferences of FOCAC ${ }^{3}$

\begin{tabular}{|c|c|c|c|}
\hline Year & Place & Conference & Documents \\
\hline 2000 & $\begin{array}{l}\text { Beijing, } \\
\text { China }\end{array}$ & $\begin{array}{l}\text { The first Ministerial } \\
\text { Conference }\end{array}$ & $\begin{array}{l}\text { Beijing Declaration of the FOCAC } \\
\text { (hereinafter, } 2000 \text { Beijing Declaration) } \\
\text { Programme for China-Africa Cooperation } \\
\text { in Economic and Social Development } \\
\text { (hereinafter, 2000 Programme) }\end{array}$ \\
\hline 2003 & $\begin{array}{c}\text { Addis } \\
\text { Ababa, } \\
\text { Ethiopia }\end{array}$ & $\begin{array}{l}\text { The second } \\
\text { Ministerial } \\
\text { Conference }\end{array}$ & $\begin{array}{l}\text { FOCAC Addis Ababa Action Plan } \\
\text { (2004-2006) (hereinafter, } 2003 \text { Action Plan) }\end{array}$ \\
\hline 2006 & $\begin{array}{l}\text { Beijing, } \\
\text { China }\end{array}$ & $\begin{array}{l}\text { The first FOCAC } \\
\text { Summit and the } \\
\text { third Ministerial } \\
\text { Conference* }\end{array}$ & $\begin{array}{l}\text { Beijing Declaration of the FOCAC } \\
\text { (hereinafter, } 2006 \text { Declaration) } \\
\text { The FOCAC Beijing Action Plan (2007-2009) } \\
\text { (hereinafter, } 2006 \text { Action Plan) }\end{array}$ \\
\hline 2009 & $\begin{array}{c}\text { Sharm } \\
\text { el-Sheikh, } \\
\text { Egypt }\end{array}$ & $\begin{array}{l}\text { The fourth } \\
\text { Ministerial } \\
\text { Conference }\end{array}$ & $\begin{array}{l}\text { Declaration of Sharm El Sheikh of the FOCAC } \\
\text { (hereinafter, 2009 Declaration) } \\
\text { FOCAC Sharm El Sheikh Action Plan } \\
\text { (2010-2012) (hereinafter, } 2009 \text { Action Plan) }\end{array}$ \\
\hline
\end{tabular}




\begin{tabular}{|c|c|c|c|}
\hline 2012 & $\begin{array}{l}\text { Beijing, } \\
\text { China }\end{array}$ & $\begin{array}{c}\text { The fifth Ministerial } \\
\text { Conference }\end{array}$ & $\begin{array}{l}\text { Beijing Declaration of the Fifth Ministerial } \\
\text { Conference of the FOCAC } \\
\text { (hereinafter, } 2012 \text { Declaration) } \\
\text { The Fifth Ministerial Conference of the } \\
\text { FOCAC Beijing Action Plan (2013-2015) } \\
\text { (hereinafter, } 2012 \text { Action Plan) }\end{array}$ \\
\hline 2015 & $\begin{array}{c}\text { Johannesburg, } \\
\text { South Africa }\end{array}$ & $\begin{array}{l}\text { The second FOCAC } \\
\text { Summit and } \\
\text { sixth Ministerial } \\
\text { Conference* }\end{array}$ & $\begin{array}{l}\text { Declaration of the Johannesburg Summit of } \\
\text { the FOCAC (hereinafter, 2015 Declaration) } \\
\text { The FOCAC Johannesburg Action Plan } \\
\text { (2016-2018) (hereinafter, } 2015 \text { Action Plan) }\end{array}$ \\
\hline 2018 & $\begin{array}{l}\text { Beijing, } \\
\text { China }\end{array}$ & $\begin{array}{l}\text { The third FOCAC } \\
\text { Summit and } \\
\text { seventh Ministerial } \\
\text { Conference* }\end{array}$ & $\begin{array}{l}\text { The Beijing Declaration -- Toward an Even } \\
\text { Stronger China-Africa Community with a } \\
\text { Shared Future (hereinafter, 2018 Declaration) } \\
\text { The FOCAC Beijing Action Plan (2019-2021) } \\
\text { (hereinafter, } 2018 \text { Action Plan) }\end{array}$ \\
\hline
\end{tabular}

\section{The Investment-related Initiatives of FOCAC}

To be concrete, investment-related initiatives of the FOCAC can be summarized into four sections: investment promotion, investment protection, investment facilitation, and dispute resolution. In the beginning, the investment-related initiatives mainly covered investment promotion and investment protection. Investment facilitation appeared occasionally. It was not until the 2015 Johannesburg Ministerial Conference that the importance of investment facilitation was attached and the new pattern of investment dispute resolution was built.

\section{Investment Promotion}

Investment promotion is the major content of investment initiatives of the FOCAC. In all action plans and declarations of the FOCAC, there is a statement for encouraging the mutual investment. In 2000, the FOCAC brought out the investment promotion in six aspects. 
1. Mutual investment should be encouraged. ${ }^{5}$

2. An initiative to set up special funds for investment should be brought up. ${ }^{6}$

3. Research on free and special economic zones should begin. ${ }^{7}$

4. Investment in common projects should be in progress. ${ }^{8}$

5. The Joint Business Council should organize regular business meetings. ${ }^{9}$

6. The finance schemes to implement mutual investment and economic partnership between China and Africa should be prepared. ${ }^{10}$

In 2003, the FOCAC further proposed that increase of investment in resources support the principle of mutual benefit, reciprocity and sustainable development. ${ }^{1}$ In 2006, the FOCAC gave continued encouragement and support for mutual investment. ${ }^{12}$ Accordingly, a China-Africa Development Fund was set up and supported by China to encourage well-established and reputable Chinese companies in making investment in projects in Africa which will contribute to local technological progress, employment opportunities and sustainable socioeconomic development. ${ }^{13}$ In 2009, China offered to increase the size of the ChinaAfrica Development Fund to USD 3 billion to expand the Chinese investment in Africa. ${ }^{14}$ Overseas business cooperation zones in Africa were also established. ${ }^{15}$ In 2012, cooperation in investment was further elaborated. ${ }^{16}$ In 2015, China planned to increase the stock of direct investment in Africa from USD 32.4 billion in 2014 to USD 100 billion in $2020 .^{17}$ China and Africa will also encourage mutual investment. $^{18}$

In 2018, China and Africa finally proposed to encourage and support mutual investment. The Chinese government will increase the investment in Africa and encourage Chinese companies to make at least USD 10 billion of investment in Africa for the next three years. ${ }^{19}$ This goal is based on the figure set up in the 2015 Johannesburg Conference. Especially, China plans to invest in manufacturing, agriculture, financial service, trade and logistics, and digital economy. ${ }^{20}$ In the investment cooperation, China is committed to the principles of no political strings, mutual benefits and efficient development to support Africa's pursuit of diversified and sustainable development. ${ }^{21}$

In sum, there are three features about the investment promotion of the FOCAC. Firstly, there exist consistent encouragement and clear goals of investment. Every action plan and declaration emphasizes on mutual investment. In the 2015 and 
2018 action plans, the clear goals for investment development were put forward. Secondly, there exists specific institutions and mechanisms for investment promotion. The China-Africa Development Fund was set up in 2006 for this purpose. This includes business cooperation zones, Joint Business Council, etc. Thirdly, the investment promotion is adhered to the principle of sustainable and mutual development. There exists consistent expressions of mutual benefit and the sustainable development in the action plans and declarations.

\section{Investment Protection}

Investment protection of the FOCAC appears in all action plans of the FOCAC, including the protection from not only domestic, but also international law.

In 2000, the FOCAC proposed to protect investment based on domestic law. The 2000 Programme proposed to grant each other preferential treatment in conformity with existing national laws, equitable treatment to all investors together with investment guarantees. ${ }^{22}$

Since 2000, the FOCAC has further proposed to protect investment based on international law, which facilitated the negotiation of Bilateral Investment Treaty ("BIT"). In 2003, African countries were encouraged to conclude bilateral agreements on investment protection with China. ${ }^{23}$ In 2006, they decided to facilitate the negotiation, conclusion and implementation of the Agreement on Bilateral Facilitation and Protection of Investment. ${ }^{24}$ The similar proposals can be seen in Section 4.2.2 of 2009 Action Plan, Section 4.2.2 of 2012 Action Plan, Section 3.7.2 of 2015 Action Plan, and Section 3.7.2 of 2018 Action Plan. In 2018, China specifically proposes to protect the legitimate rights and interests of companies in China with investment from African countries. ${ }^{25}$

On the one hand, the investment protection in the FOCAC shows the reliance on the BIT to protect foreign investors. On the other hand, the investment protection in the FOCAC has more emphasis on mutual protection and the protection from domestic law.

\section{Investment Facilitation}

Investment facilitation does not appear in every action plan and declaration of the FOCAC. It was brought out only in 2003 and 2006 Action Plans. Since 2015, investment facilitation has become more important. 
In 2003 and 2006, it was proposed to take investment facilitation measures in terms of administrative approval procedures. In 2003, both sides agreed to take investment facilitation measures together by focusing on simplifying the approval procedures for Chinese companies, which are interested in investing in Africa. ${ }^{26}$ In 2006, they pledged the facilitation necessary in terms of administrative approval procedures, customs clearance and border entry and exit for company investors of the two sides. ${ }^{27}$

In 2015, investment facilitation becomes one of the 10 major China-Africa cooperation plans in the FOCAC. China proposed to help Africa improve its domestic software and hardware conditions of investment. ${ }^{28}$ It was proposed to improve the investment facilitation by the means of pushing forward the cooperation in E-commerce. In 2018, Africa proposed to create a more enabling environment for attracting investment from Chinese enterprises. ${ }^{29}$

This trend is in conformity with developing countries' proposal of investment facilitation in the WTO and the discussion of investment facilitation issue in international organizations.

\section{Investment Dispute Resolution}

Basically, investment dispute resolution was not included in the FOCAC until 2015. In 2000, there was merely a statement about just settlement of eventual disputes in accordance with internationally accepted rules and practices. ${ }^{30}$

Things changed in 2015, when the FOCAC firstly came up with an initiative specializing in the investment dispute resolution. The China-Arica Joint Arbitration Center ("CAJAC") was set up in order to resolve investor-state and commercial disputes between China and Africa. ${ }^{31}$ In 2018, China and Africa agree to further improve the CAJAC. ${ }^{32}$ This change relates to the legitimacy crisis and the reform of the investor-state dispute settlement system. It also implies China's desire to create a new choice for dispute settlement.

\section{Implications of Investment-related Initiatives of FOCAC on China-Africa Investment Relationship}

In the 2018 FOCAC Beijing Summit, China declared to fully implement the 10 cooperation plans adopted in the 2015 FOCAC Johannesburg Summit. ${ }^{33}$ These 
investment-related initiatives fulfill the objectives of the FOCAC. The FOCAC has a vital importance on the China-Africa investment relationship. The effects of investment-related initiatives of the FOCAC can be seen in five aspects.

Firstly, mutual investment achieved great success. China's FDI stock in Africa was approximately USD 500 million in $2000 .{ }^{34}$ Since the FOCAC, the FDI stock in Africa from China has increased (Figure 1). In this regard, the FDI flows to Africa from China are fluctuating but generally increasing as well (Figure 2). Also, the FDI flows from Africa to China are increasing. As of 2016, Africa's non-financial investment in China was twice that of 2002 (Figure 3). Although the FDI flows in Africa from China accounted for only a small amount of African FDI inflow, these statistics generally show that the initiatives in action plans and declarations of the FOCAC are more than words, but rather the guidance of actions.

Figure 1: FDI Stock in Africa from China (2003-17) (Millions of USD) ${ }^{35}$

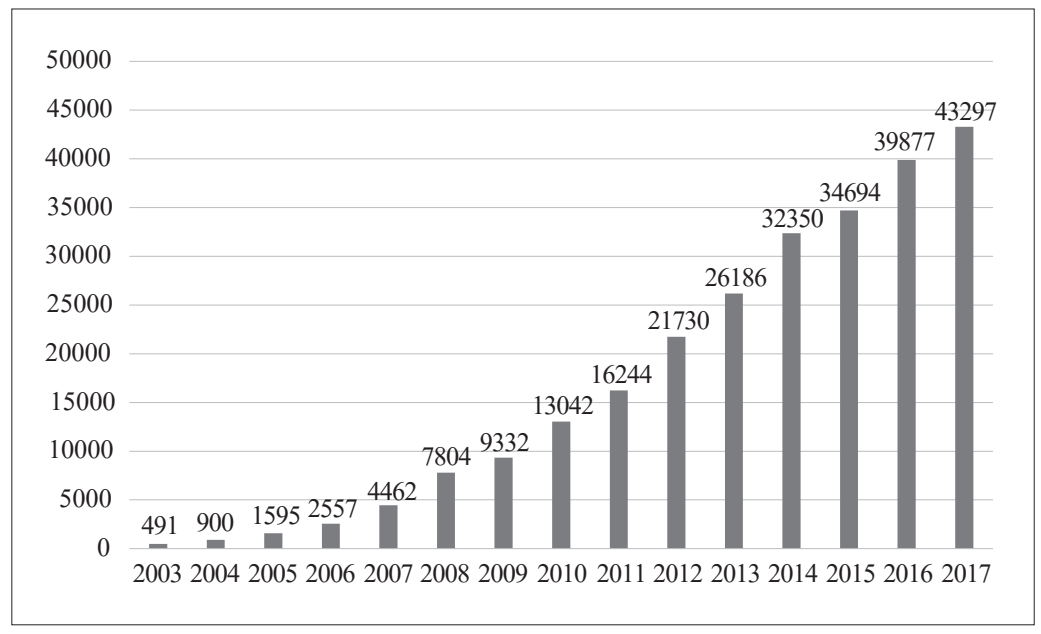


Figure 2: FDI Flows to Africa from China (2003-17) (Millions of USD) ${ }^{36}$

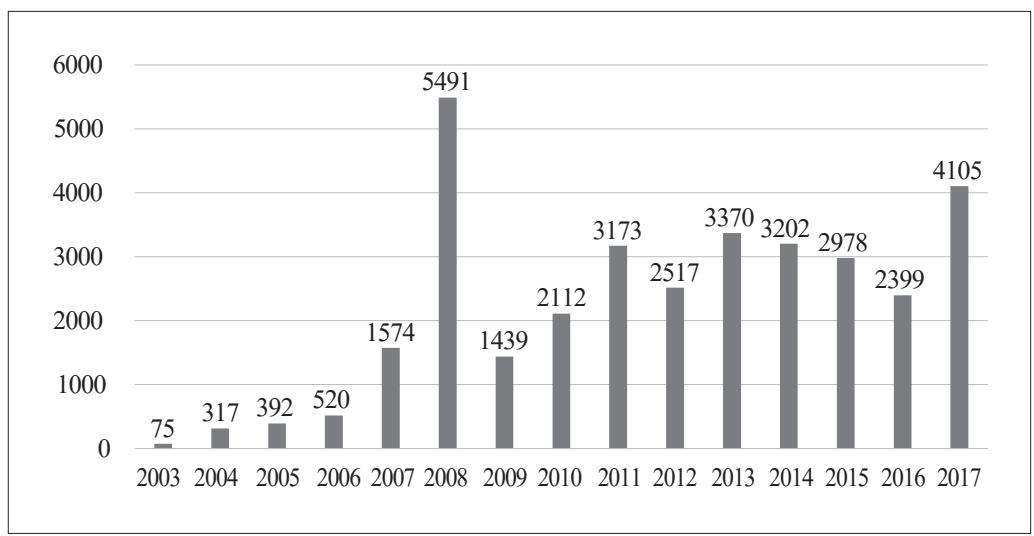

Figure 3: FDI Flows to China from Africa (2003-12, 2015-17) (Millions of USD) ${ }^{37}$

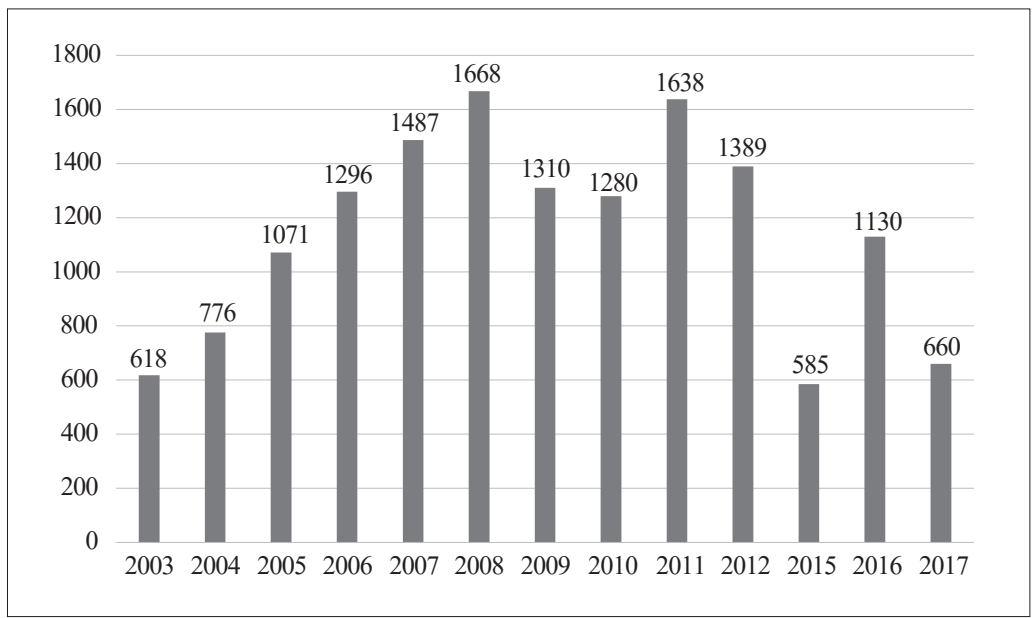

Secondly, investment facilitation has initial outcomes. The negotiation for the free trade agreement is in progress, which will provide a better institutional system for investment. In 2018, China and Mauritius prepared for the final signing of a bilateral free trade agreement, which will be the first free trade agreement between China and an African country. ${ }^{38}$ The CA-B2B website was built in June 2018, providing online service for contract signing, payment, and customs declaration. ${ }^{39}$ 
Thirdly, investment protection is still in progress. In 2015, China and Africa had 33 BITs, 19 of which are in force. ${ }^{40}$ Since 2016, there has been no new BIT negotiation or implementation between China and African countries. This indicates the non-obligatory character of the investment-related initiatives. The next step of investment protection should focus on the entry into force of BITs or the renewal of their contents.

Fourthly, new choice of investment dispute resolution is provided. Set up and carried forward by the FOCAC, nowadays, the CAJAC can resolve both commercial and investor-state disputes. CAJAC has set up three centers in China (Shanghai, Beijing, and Shenzhen) and two centers in Africa (Johannesburg and Nairobi). Now, it has become a new option for China and Africa to resolve the investment disputes between them.

In sum, investment-related initiatives of the FOCAC have achieved great success with positive effects on fulfilling the objectives and purposes of the FOCAC.

\section{Conclusion}

The investment-related initiatives proposed in the FOCAC cover investment promotion, investment protection, investment facilitation, and investment dispute resolution. Although the negotiation of the BIT has stalled, the effect of these initiatives cannot be ignored. There is still a long way to go. For the first time, the 2018 Beijing Summit proposed to build a community of a shared future for mankind. In order to further fulfill its objectives, the FOCAC can improve the investment-related initiatives from these following aspects. On one hand, investment-related initiatives should be in accordance with the f ISDS reform and the sustainable development of BIT provisions, while insisting on the mutual development. On the other hand, it will be more enforceable if the proposed initiatives can come along with some binding rules as well as non-mandatory agreements. In this way, President Xi Jinping addressed: “Africa's development has great potential, China-Africa friendship and cooperation have broad vistas, and China and Africa can forge an even stronger comprehensive strategic and cooperative partnership." 


\section{REFERENCES}

1. See FOCAC Mechanisms, available at https://www.focac.org/eng/ltjj_3/ltjz (last visited on Feb. 14, 2019).

2. Id.

3. For the development of China-Africa relationship, China and Africa decided to upgrade the third, sixth, and seventh Ministerial Conference to the level of Summit. For details on the previous conferences of FOCAC, see the official website of FOCAC, available at https:// www.focac.org/eng/lihy_1/dyjbzjhy_1/CI12009 (last visited on Feb. 14, 2019).

4. 2000 Declaration. See also 2000 Programme $\S \S 3-5$.

5. Id. $\S 5.1$.

6. Id. $\S 5.2$.

7. Id. $\S 5.3$.

8. Id. $\S 5.4$.

9. Id. $\S 5.5$.

10. Id. $\S 5.6$.

11. 2003 Action Plan $\S 4.8 .2$.

12. 2006 Action Plan $\S \S 3.1 .3$ \& 3.2.1.

13. Id. $\S 3.2 .5$.

14. 2009 Action Plan $\S 4.2 .3$.

15. Id. $\S 4.2 .4$.

16. 2012 Declaration. See also 2012 Action Plan $\S 4.2$.

17. 2015 Action Plan $\S 3.7 .1$.

18. Id. $\S 3.7 .2$.

19. 2018 Action Plan $\S 3.7 .2$.

20. See Elaboration on the Eight Major Initiatives of the FOCAC Beijing Summit, available at http://english.mofcom.gov.cn/article/policyrelease/Cocoon/201809/2018 0902788698. shtml (last visited on Feb. 14, 2019).

21. 2018 Action Plan $\S 3.9 .2$.

22. 2000 Programme $\S 3.3$.

23. 2003 Action Plan $\S 4.4 .3$.

24. 2006 Action Plan $\S 3.2 .2$.

25. 2018 Action Plan $\S 3.8 .10$.

26. 2003 Action Plan $\S 4.4 .3$.

27. 2006 Action Plan $\S 3.2 .2$.

28. See Section VI of the Interpretations of the Johannesburg Summit of the FOCAC and the Sixth Ministerial Conference on the 10 Major China-Africa Cooperation Plans in Economic and Trade Domains, available at http://english.mofcom.gov.cn/article/ policyrelease/Cocoon/201512/20151201219036.shtml (last visited on Feb. 14, 2019). 
29. 2018 Action Plan $\S 3.2 .5$.

30. The 2000 Programme proposed to conclude an appropriate legal framework on encouragement, protection and guarantee of investments, to undertake joint efforts to improve investment environment through such measures as granting each other preferential treatment in conformity with existing national laws, equitable treatment to all investors together with investment guarantees and just settlement of eventual disputes, in accordance with internationally accepted rules and practices.

31. 2015 Action Plan $\S$ 6.2.6.

32. 2018 Action Plan $\S 6.2 .12$.

33. See the full text of Chinese President Xi Jinping's speech at opening ceremony of 2018 FOCAC Beijing Summit, available at http://www.globaltimes.cn/content/1118205.shtml (last visited on Feb. 14, 2019).

34. From 2003, China began to regularly publish the statistics about FDI. The statistics before 2003 can be acquired through other official reports or declarations. China's total nonfinancial investment in Africa in 2014 was reportedly 60 times that of 2000 respectively. See the full text of Xi Jinping's address at opening ceremony of FOCAC summit, available at http://www.china.org.cn/chinese/2015-12/07/content_37255657.htm (last visited on Feb. 14, 2019).

35. See 2009 Statistical Bulletin of China's Outward Foreign Direct Investment (China Statistics Press, 2010); 2017 Statistical Bulletin of China's Outward Foreign Direct Investment (China Statistics Press, 2018).

36. See 2009 Statistical Bulletin of China's Outward Foreign Direct Investment (China Statistics Press, 2010); 2017 Statistical Bulletin of China's Outward Foreign Direct Investment (China Statistics Press, 2018).

37. For the statistics, see Report on Foreign Investment in China (2012, 2015, 2016, 2017 \& 2018). The statistics in 2013 and 2014 are not available.

38. See China, Mauritius set to sign free trade agreement, Xinhuanet, Sept. 3, 2018 , available at http://www.xinhuanet.com/english/2018-09/03/c_137441669.htm (last visited on Feb. 14, 2019).

39. See Full implementation of the "Top Ten Cooperation Plans" to provide strong support, Daily Econ. News, Sept. 4, 2018, available at http://westdollar.com/sbdm/finance/ news/1351,20180904939175455.html (last visited on Feb. 14, 2019).

40. Statistics come from China Treaty Database, available at http://treaty.mfa.gov.cn (last visited on Feb. 14, 2019).

41. See the full text of Chinese President Xi Jinping's speech at opening ceremony of 2018 FOCAC Beijing Summit, available at http://www.xinhuanet.com/english/2018-09/03/ c_129946189.htm (last visited on Feb. 14, 2019). 
